NASA/TM-2000-209891, Vol. 142

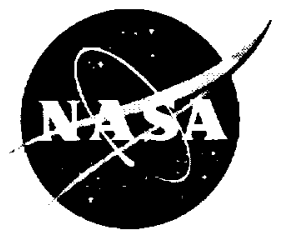

Technical Report Series on the Boreal Ecosystem-Atmosphere Study (BOREAS)

Forrest G. Hall and Shelaine Curd, Editors

Volume 142

BOREAS TE-5 Tree Ring and Carbon Isotope Ratio Data

J. Ehleriinger; J.R. Brooks, and L. Flanagan

National Aeronautics and

Space Administration

Goddard Space Flight Center

Greenbelt, Maryland 20771 
The NASA STI Program Office ... in Profile

Since its founding, NASA has been dedicated to the advancement of aeronautics and space science. The NASA Scientific and Technical Information (STI) Program Office plays a key part in helping NASA maintain this important role.

The NASA STI Program Office is operated by Langley Research Center, the lead center for NASA's scientific and technical information. The NASA STI Program Office provides access to the NASA STI Database, the largest collection of aeronautical and space science STI in the world. The Program Office is also NASA's institutional mechanism for disseminating the results of its research and development activities. These results are published by NASA in the NASA STI Report Series, which includes the following report types:

- TECHNICAL PUBLICATION. Reports of completed research or a major significant phase of research that present the results of NASA programs and include extensive data or theoretical analysis. Includes compilations of significant scientific and technical data and information deemed to be of continuing reference value. NASA's counterpart of peer-reviewed formal professional papers but has less stringent limitations on manuscript length and extent of graphic presentations.

- TECHNICAL MEMORANDUM. Scientific and technical findings that are preliminary or of specialized interest, e.g., quick release reports, working papers, and bibliographies that contain minimal annotation. Does not contain extensive analysis.

- CONTRACTOR REPORT. Scientific and technical findings by NASA-sponsored contractors and grantees.
- CONFERENCE PUBLICATION. Collected papers from scientific and technical conferences, symposia, seminars, or other meetings sponsored or cosponsored by NASA.

- SPECIAL PUBLICATION. Scientific, technical, or historical information from NASA programs, projects, and mission, often concerned with subjects having substantial public interest.

- TECHNICAL TRANSLATION. English-language translations of foreign scientific and technical material pertinent to NASA's mission.

Specialized services that complement the STI Program Office's diverse offerings include creating custom thesauri, building customized databases, organizing and publishing research results ... even providing videos.

For more information about the NASA STI Program Office, see the following:

- Access the NASA STI Program Home Page at http://www.sti.nasa.gov/STI-homepage.html

- E-mail your question via the Internet to help@sti.nasa.gov

- Fax your question to the NASA Access Help Desk at (301) 621-0134

- Telephone the NASA Access Help Desk at (301) 621-0390

- Write to:

NASA Access Help Desk

NASA Center for AeroSpace Information 7121 Standard Drive

Hanover, MD 21076-1320 
NASA/TM-2000-209891, Vol. 142

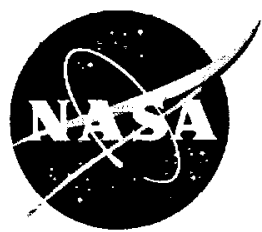

\section{Technical Report Series on the} Boreal Ecosystem-Atmosphere Study (BOREAS)

Forrest G. Hall and Shelaine Curd, Editors

\section{Volume 142 \\ BOREAS TE-5 Tree Ring and Carbon Isotope Ratio Data}

Jim Ehleriinger, University of Utah, Salt Lake City

J. Renee Brooks, University of South Florida, Tampa

Larry Flanagan, University of Lethbridge, Lethbridge, Alberta, Canada

National Aeronautics and

Space Administration

Goddard Space Flight Center

Greenbelt, Maryland 20771 
Available from:

NASA Center for AeroSpace Information

7121 Standard Drive

Hanover, MD 21076-1320

Price Code: A17
National Technical Information Service 5285 Port Royal Road Springfield, VA 22161

Price Code: A10 


\title{
BOREAS TE-5 Tree Ring and Carbon Isotope Ratio Data
}

\author{
Jim Ehleringer, J.Renee Brooks, Larry Flanagan
}

\section{Summary}

The BOREAS TE-5 team collected several data sets to investigate the vegetation-atmosphere $\mathrm{CO}_{2}$ and $\mathrm{H}_{2} \mathrm{O}$ exchange processes. These data include tree ring widths and cellulose carbon isotope data from coniferous trees collected at the BOREAS NSA and SSA in 1993 and 1994 by the BOREAS TE-05 team. Ring width data are provided for both Picea mariana and Pinus banksiana. The carbon isotope data are provided only for Pinus banksiana. The data are provided in tabular ASCII files.

\section{Table of Contents}
1) Data Set Overview
2) Investigator(s)
3) Theory of Measurements
4) Equipment
5) Data Acquisition Methods
6) Observations
7) Data Description
8) Data Organization
9) Data Manipulations
10) Errors
11) Notes
12) Application of the Data Set
13) Future Modifications and Plans
14) Software
15) Data Access
16) Output Products and Availability
17) References
18) Glossary of Terms
19) List of Acronyms
20) Document Information

\section{Data Set Overview}

\subsection{Data Set Identification \\ BOREAS TE-05 Tree Ring and Carbon Isotope Ratio Data}

\subsection{Data Set Introduction}

Tree ring widths were collected from trees from Old Black Spruce (OBS) in the BOReal Ecosystem-Atmosphere Study (BOREAS) Southern Study Area (SSA), Upland Black Spruce (UBS) in the Northern Study Area (NSA), and Old Jack Pine (OJP) in the SSA and the NSA. The carbon isotope ratio of cellulose was measured on individual tree rings from 1974 to 1994 for the OJP sites, two trees from each site.

\subsection{Objective/Purpose}

The purpose of this study was to measure year-to-year variation in ring widths and carbon isotope ratios in the conifers at the northern and southern sites. These data were compared with year-to-year variations on meteorological measurements in an attempt to find whether variables have influenced both diameter growth and carbon isotope discrimination. Investigators studied whether controlling climate variables were the same in the north as in the south. 


\subsection{Summary of Parameters and Variables}

Annual ring widths (mm)

Carbon isotope ratios

\subsection{Discussion}

Tree cores were collected at both the NSA and SSA in both 1993 and 1994 at the OJP, OBS, and OBS (T6R56) sites. These data can be compared to determine differences in growth rates and possible effects of climate variables during the time frame recorded by tree ring widths. The tree ring isotope data ranges can be used to determine the relative concentration of $\mathrm{C}$ isotopes based on knowing the relative assimilation by trees at different sites.

\subsection{Related Data Sets}

BOREAS TE-05 Diumal CO2 Canopy Profile Data

BOREAS TE-05 Leaf Carbon Isotope Data

International tree ring data base (http://tree.Itrr.arizona.edu/ grissino/itrdb.htm)

\section{Investigator(s)}

\subsection{Investigator(s) Name and Title}

Jim Ehleringer

SIRFER

Dept. of Biology

University of Utah

Dr. Larry Flanagan

Department of Biological Sciences

University of Lethbridge

\subsection{Title of Investigation}

Vegetation-Atmosphere $\mathrm{CO}_{2}$ and $\mathrm{H}_{2} \mathrm{O}$ Exchange Processes: Stable Isotope Analyses

\subsection{Contact Information}

\section{Contact 1:}

J. Renèe Brooks

Department of Biology

University of South Florida

Tampa, FL 33620-5150

(813) $974-7352$

(813) 974-3563 (fax)

jrbrooks@chuma.cas.usf.edu

\section{Contact 2:}

Dr. Larry Flanagan

Department of Biological Sciences

University of Lethbridge

4401 University Drive

Lethbridge, Alberta

T1K 3M4, CANADA 


\section{Contact 3:}

Shelaine Curd

Raytheon ITSS

Code 923

NASA GSFC

Greenbelt, MD 20771

(301) 286-2447

(301) 286-0239 fax

shelaine.curd@gsfc.nasa.gov

\section{Theory of Measurements}

Annual variation in tree ring width represents variation in stem growth. Annual variation in delta $13 \mathrm{C}$ of cellulose represents the annual variation of carbon isotope discrimination by the tree. For complete information on stable carbon isotope ratios, see Coleman and Fry (1991). The stable carbon isotope ratio $(13 \mathrm{C} / 12 \mathrm{C})$ is not presented as an absolute but as the relative difference between the isotope ratios of the sample and standard gases: delta $13 \mathrm{C}(\mathrm{o} / \mathrm{oo})=(($ Rsample / Rstandard $)-1) * 1000$, where Rsample and Rstandard are the $13 \mathrm{C} / 12 \mathrm{C}$ ratios of the plant sample and standard Pee Dee Belemite (PDB). The overall precision of the measurements of cellulose materials was $\pm 0.11 \mathrm{o} / \mathrm{oo}$.

\section{Equipment}

\subsection{Sensor/Instrument Description}

Isotope ratio mass spectrometer (delta S, Finnigan Mat, San Jose, CA). Measuring stage for tree ring widths (Fred C. Henson, Mission Viego, CA).

\subsubsection{Collection Environment}

NSA and SSA black spruce and jack pine sites. Carbon isotopes of cellulose were measured only for the last 20 years of growth (1994-1974).

\subsubsection{Source/Platform}

Dominant conifer trees, which were considered to be those trees that were clearly taller than the surrounding trees, were chosen.

\subsubsection{Source/Platform Mission Objectives}

The purpose of this study was to understand the relationship between environmental variables and annual variation in tree ring widths and carbon isotope ratios.

\subsubsection{Key Variables}

Year

Annual ring widths $(\mathrm{mm})$

Annual cellulose carbon isotope ratios

\subsubsection{Principles of Operation}

None.

\subsubsection{Sensor/Instrument Measurement Geometry}

Not applicable. 


\author{
4.1.7 Manufacturer of Sensor/Instrument \\ Mass spectrometer: \\ Finnigan Mat \\ 355 River Oaks Parkway \\ San Jose, CA 95134 \\ (404) 424-5284 \\ Measuring stage: \\ Fred C. Henson Co. \\ 28362 Marguerite Parkway \\ Mission Viego, CA 92691-1523 \\ (714) 831-9192
}

\title{
4.2 Calibration
}

Ring width calibration: Calibration on the measuring stage was checked prior to each use. The nature of the measuring stage is such that the calibration is extremely stable and no adjustments were ever needed.

Carbon isotope calibration: The mass spectrometer is calibrated to standard PDB gas. This international standard was a limestone of fossil Belemnitella Americana from the Cretaceous Pee Dee formation in South Carolina. In addition, a standard cellulose sample was run after every 12 cellulose samples.

\subsubsection{Specifications}

None.

\subsubsection{Tolerance}

Annual ring widths:

Precision: $0.01 \mathrm{~mm}$

Carbon isotope ratio

Precision: 0.1

\subsubsection{Frequency of Calibration}

Mass spectrometer: 1 in every 12 samples was a cellulose standard. Mass spectrometers are maintained by Craig Cook at the University of Utah.

Measuring stage: Calibration was tested prior to every use.

\subsubsection{Other Calibration Information \\ None.}

\section{Data Acquisition Methods}

At each site, four to six dominant trees were cored or slabs were collected for analysis. All slabs and cores were collected at breast height $(1.3 \mathrm{~m})$. Slabs were collected from trees that were destructively harvested for biomass estimates (see other BOREAS Terrestrial Ecology (TE)-06 documentation). In the lab, slabs and cores were sanded so that tree rings were clearly visible. For each tree, ring widths were measured from two directions and averaged together. Prior to measuring ring widths, tree rings were counted along both measuring directions and checked to ensure that each count was the same. Skeletal plots were created for each tree and compared for all trees within a plot to ensure comparable dating for all the trees. Aging these trees was very straightforward from diameter at breast height $(\mathrm{dbh})$; however, it was understated that this is not the absolute age of the tree because time and growth were needed for the tree to reach $\mathrm{dbh}$ (for more details see: Cook and Kairiukstis, 1990). Each tree ring chronology begins at the last year of growth (1993 or 1994, depending on when the sample was collected) and ends at the year the tree reached $1.3 \mathrm{~m}$ (center of the slab). 
Carbon isotopes of cellulose were measured only for the last 20 years of growth (1994-1974). To collect enough cellulose material for isotope analyses, only tree slabs were used. For each year, sample material was collected from four sides of the slab to ensure annual uniformity. Tree rings were carefully separated using an exacto knife while viewed under a $40 \mathrm{x}$ dissecting scope. Care was taken to include tissue only from the year of interest in the sample. Cellulose was extracted from the wood samples following the method outlined in Leavitt and Danzer (1992). Cellulose samples were then analyzed on the mass spectrometer for delta $13 \mathrm{C}$.

\section{Observations}

\subsection{Data Notes \\ None given.}

\subsection{Field Notes \\ None given.}

\section{Data Description}

\subsection{Spatial Characteristics}

\subsubsection{Spatial Coverage}

The North American Datum of 1983 (NAD83) coordinates of the sites are:

- NSA-OJP flux tower site: Lat/Long: $55.927^{\circ} \mathrm{N}, 98.62^{\circ} \mathrm{W}$; Universal Transverse Mercator (UTM) Zone 14, N:6,197,997 E:523,501.

- SSA-OJP flux tower site: Lat/Long: $53.916^{\circ} \mathrm{N}, 104.69^{\circ} \mathrm{W}$ : UTM Zone $13, \mathrm{~N}: 5,951,000$ E: 479,400 .

- $\quad$ NSA-UBS canopy access tower site (auxiliary site number T6R5S, BOREAS Experiment Plan, Version 3).

- $\quad$ SSA-OBS flux tower site: Lat/Long: $53.985^{\circ} \mathrm{N}, 105.122^{\circ} \mathrm{W}$; UTM Zone $13, \mathrm{~N}: 5,981,904$ E:492,000.

\subsubsection{Spatial Coverage Map}

Not available.

\subsubsection{Spatial Resolution}

These data represent point measurements of the sampled trees that may be representative of a larger area.

\subsubsection{Projection}

Not applicable.

\subsubsection{Grid Description}

Not applicable.

\subsection{Temporal Characteristics}

Not applicable.

\subsubsection{Temporal Coverage}

Ring width measurements:

NSA-OJP: 1994-1939

NSA-UBS (T6R5S): 1994-1944 
SSA-OJP: 1994-1902

SSA-OBS: 1994-1867

Carbon isotope data:

NSA-OJP and SSA-OJP: 1994-1974

\subsubsection{Temporal Coverage Map}

Not applicable.

\subsubsection{Temporal Resolution} Annual.

\subsection{Data Characteristics}

\subsubsection{Parameter/Variable}

The parameters contained in the data files on the CD-ROM are:

Column Name
SITE_NAME
SUB_SITE
START_DATE
END_DATE
SPECIES
TREE_RING_YEAR
TREE
TREE_RING_WIDTH
CELLULOSE_DELTA_C13
CRTFCN_CODE
REVISION_DATE

\subsubsection{Variable Description/Definition}

The descriptions of the parameters contained in the data files on the CD-ROM are:

\begin{tabular}{|c|c|}
\hline Column Name & Description \\
\hline SITE_NAME & $\begin{array}{l}\text { The identifier assigned to the site by BOREAS, } \\
\text { in the format SSS-TTT-CCCCC, where SSS identifies } \\
\text { the portion of the study area: NSA, SSA, REG, } \\
\text { TRN, and TTT identifies the cover type for the } \\
\text { site, } 999 \text { if unknown, and CCCCC is the identifier } \\
\text { for site, exactly what it means will vary with } \\
\text { site type. }\end{array}$ \\
\hline SUB_SITE & $\begin{array}{l}\text { The identifier assigned to the sub-site by } \\
\text { BOREAS, in the format GGGGG-IIIII, where GGGGG is } \\
\text { the group associated with the sub-site } \\
\text { instrument, e.g. HYDO6 or STAFF, and IIIII is the } \\
\text { identifier for sub-site, often this wiII refer to } \\
\text { an instrument. }\end{array}$ \\
\hline START_DATE & $\begin{array}{l}\text { The date on which the collection of data } \\
\text { commenced. }\end{array}$ \\
\hline END_DATE & $\begin{array}{l}\text { The date on which the collection of the data was } \\
\text { terminated. }\end{array}$ \\
\hline SPECIES & Botanical (Latin) name of the species (Genus \\
\hline
\end{tabular}


TREE_RING_YEAR
TREE
TREE_RING_WIDTH
CELLULOSE_DELTA_C13

CRTFCN_CODE

REVISION_DATE

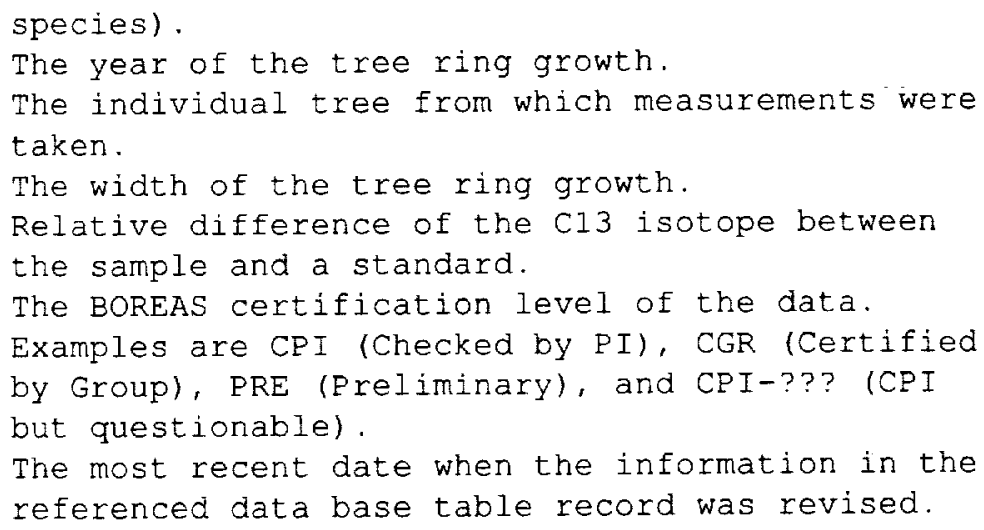

\subsubsection{Unit of Measurement}

The measurement units for the parameters contained in the data files on the CD-ROM are:

$\begin{array}{ll} & \text { Column Name } \\ & \\ \text { SITE_NAME } & \text { Units } \\ \text { SUB_SITE } & \text { [none] } \\ \text { START_DATE } & \text { [DD-MON-YY] } \\ \text { END_DATE } & \text { [DD-MON-YY] } \\ \text { SEECIES } & \text { [none] } \\ \text { TREE_RING_YEAR } & \text { [none] } \\ \text { TREE } & \text { [none] } \\ \text { TREE_RING_WIDTH } & \text { [milimeters] } \\ \text { CELLULOSE_DELTA_C13 } & \text { [unitless] } \\ \text { CRTECN_CODE } & \text { [none] } \\ \text { REVISION_DATE } & \text { [DD-MON-YY] }\end{array}$

\subsubsection{Data Source}

The sources of the parameter values contained in the data files on the CD-ROM are:

\begin{tabular}{ll}
\multicolumn{1}{c}{ CoIumn Name } & Data Source \\
SITE_NAME & [BORIS Designation] \\
SUB_SITE & [BORIS Designation] \\
START_DATE & [Human Observer] \\
END_DATE & [Human Observer] \\
SPECIES & [Human Observer] \\
TREE_RING_YEAR & [Human Observer] \\
TREE & [Human Observer] \\
TREE_RING_WIDTH & [Human Observer] \\
CELLULOSE_DELTA_C13 & [Laboratory Equipment] \\
CRTFCN_CODE & [BORIS Designation] \\
REVISION_DATE & [BORIS Designation]
\end{tabular}




\subsubsection{Data Range}

The following table gives information about the parameter values found in the data files on the CD-ROM.

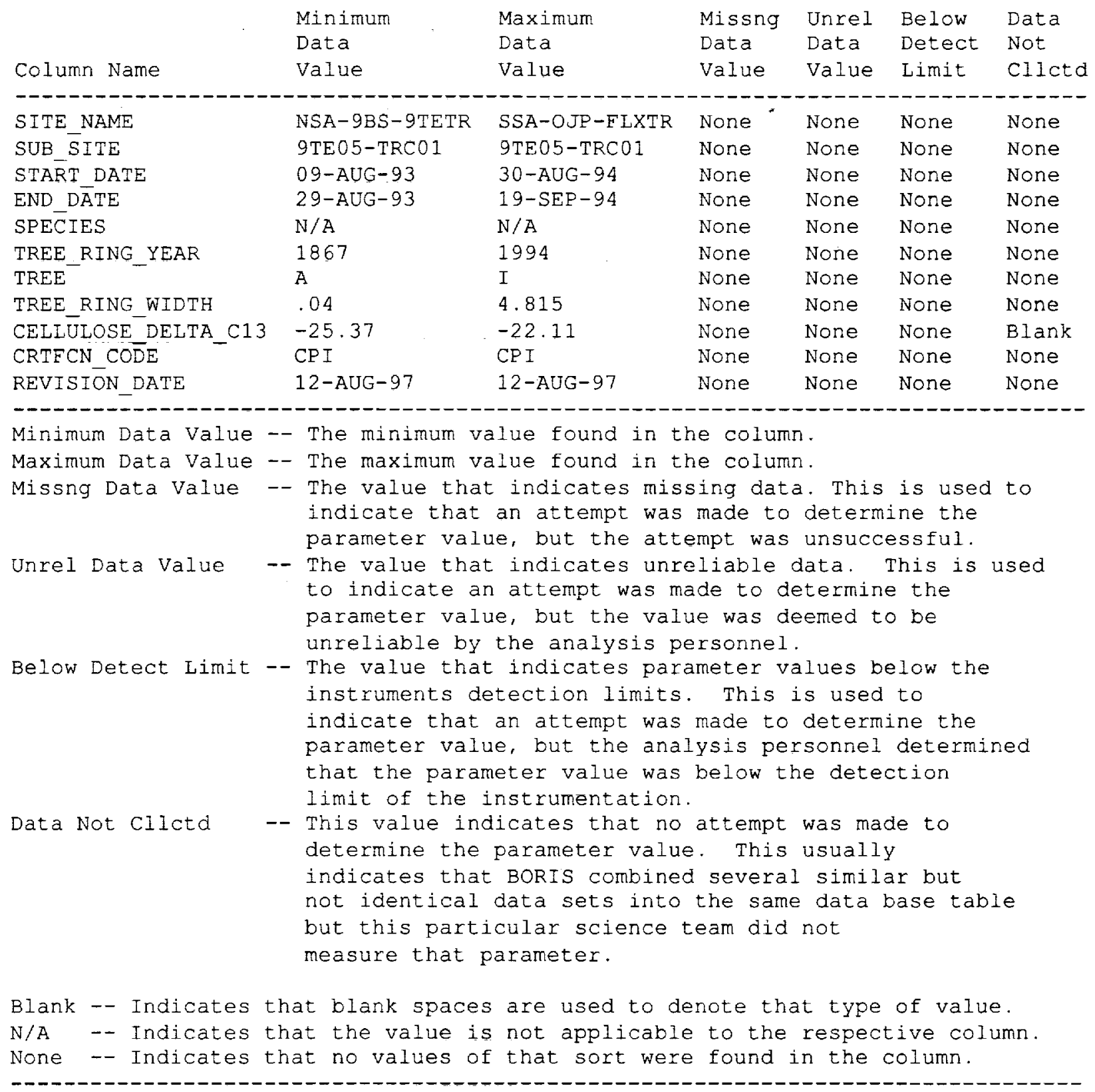

\subsection{Sample Data Record}

The following is a sample of the first few records from the data table on the CD-ROM:

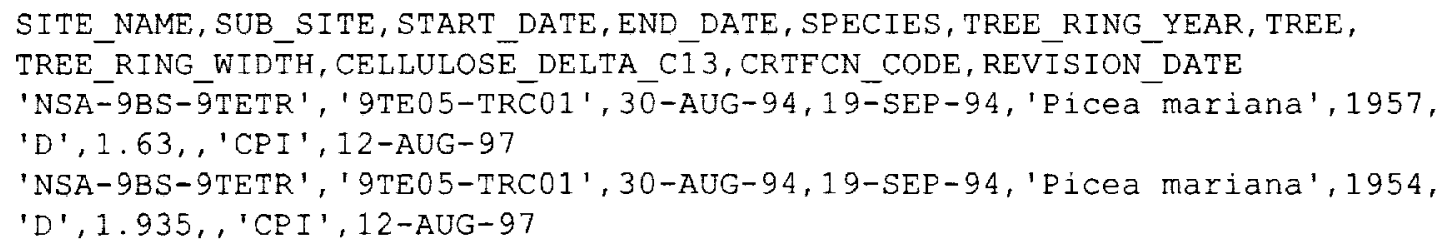

\section{Page 8}




\section{Data Organization}

\subsection{Data Granularity}

The smallest unit of data tracked by the BOREAS Information System (BORIS) was that collected at a given site on a given date.

\subsection{Data Format(s)}

The Compact Disk-Read-Only Memory (CD-ROM) files contain American Standard Code for Information Interchange (ASCII) numerical and character fields of varying length separated by commas. The character fields are enclosed with single apostrophe marks. There are no spaces between the fields.

Each data file on the CD-ROM has four header lines of Hyper-Text Markup Language (HTML) code at the top. When viewed with a Web browser, this code displays header information (data set title, location, date, acknowledgments, etc.) and a series of HTML links to associated data files and related data sets. Line 5 of each data file is a list of the column names, and line 6 and following lines contain the actual data. Each row represents an annual record beginning with the year.

\section{Data Manipulations}

\subsection{Formulae}

None.

\subsubsection{Derivation Techniques and Algorithms} None.

\subsection{Data Processing Sequence}

\subsubsection{Processing Steps}

None.

\subsubsection{Processing Changes}

None.

\section{Errors}

\subsection{Sources of Error}

Other than normal background error associated with the instrumentation, there are no other sources of error. The overall precision of the measurements of cellulose materials was $\pm 0.11 \mathrm{o} / \mathrm{oo}$.

\subsection{Quality Assessment}

None given.

\subsubsection{Data Validation by Source None given.}

10.2.2 Confidence Level/Accuracy Judgment None given.

\subsubsection{Measurement Error for Parameters None given.}




\subsubsection{Additional Quality Assessments}

None given.

\subsubsection{Data Verification by Data Center}

Data were examined for general consistency and clarity.

\section{Notes}

\subsection{Limitations of the Data}

Small sample sizes.

\subsection{Known Problems with the Data}

There are no known problems with the data.

\subsection{Usage Guidance}

None.

\subsection{Other Relevant Information}

None given.

\section{Application of the Data Set}

Tree ring and isotope data can be examined to determine previous climate conditions and how those conditions affect the growth of trees.

\section{Future Modifications and Plans}

None given.

\section{Software}

\subsection{Software Description}

The ITRDB Program Library Version 2.1 is the latest version of the ITRDB Program Library, an extensive collection of programs to acquire, manipulate, analyze, and display tree ring data; they are accompanied by extensive documentation, including online help, and run from an easy-to-use DOS-based menu. Henri D. Grissino-Mayer wrote many of the programs as well as the main menu, Richard L. Holmes contributed the famous Dendrochronology Program Library, and Edward R. Cook contributed the standardization program ARSTAN. Other contributors include Thierry Varem-Sanders, Oriol Bosch, and Paul Krusic, and to them we are very grateful. If you or anybody you work with has developed software you feel would be useful to the entire dendrochronological community, contact Henri D. Grissino-Mayer to see about incorporating the programs in the Program Library.

\subsection{Software Access}

Software access -- http://tree.ltrr.arizona.edu/ grissino/software.htm

For tree ring data: (source: Henri Grissino-Mayer http://tree.ltrr.arizona.edu/ grissino/software.htm) 


\section{Data Access}

The TE-05 tree ring and carbon isotope ratio data are available from the Earth Observing System Data and Information System (EOSDIS) Oak Ridge National Laboratory (ORNL) Distributed Active Archive Center (DAAC).

\subsection{Contact Information}

For BOREAS data and documentation please contact:

ORNL DAAC User Services

Oak Ridge National Laboratory

P.O. Box 2008 MS-6407

Oak Ridge, TN 37831-6407

Phone: (423) 241-3952

Fax: (423) 574-4665

E-mail: omldaac@oml.gov or ornl@eos.nasa.gov

\subsection{Data Center Identification}

Earth Observing System Data and Information System (EOSDIS) Oak Ridge National Laboratory (ORNL) Distributed Active Archive Center (DAAC) for Biogeochemical Dynamics http://www-eosdis.ornl.gov/.

\subsection{Procedures for Obtaining Data}

Users may obtain data directly through the ORNL DAAC online search and order system [http://www-eosdis.ornl.gov/] and the anonymous FTP site [ftp://www-eosdis.ornl.gov/data/] or by contacting User Services by electronic mail, telephone, fax, letter, or personal visit using the contact information in Section 15.1.

\subsection{Data Center Status/Plans}

The ORNL DAAC is the primary source for BOREAS field measurement, image, GIS, and hardcopy data products. The BOREAS CD-ROM and data referenced or listed in inventories on the CD-ROM are available from the ORNL DAAC.

\section{Output Products and Availability}

\subsection{Tape Products}

None.

\subsection{Film Products}

None.

\subsection{Other Products}

These data are available on the BOREAS CD-ROM series. 


\section{References}

\subsection{Platform/Sensor/Instrument/Data Processing Documentation None.}

17.2 Journal Articles and Study Reports

Coleman, D.C. and B. Fry. 1991. Carbon Isotope Techniques. Academic Press, San Diego, pp. 273.

Cook, E.R. and L.A. Kairiukstis. 1990. Methods of Dendrochronology: Applications in the Environmental Sciences. Kluwer Academic Publishers, Dordrecht, pp. 394.

Leavitt, S.W. and S.R. Danzer. 1992. Methods for batch processing small wood samples to holocellulose for stable-carbon isotope analysis. Anal. Chem. 65: 87-89.

Newcomer, J., D. Landis, S. Conrad, S. Curd, K. Huemmrich, D. Knapp, A. Morrell, J. Nickeson, A. Papagno, D. Rinker, R. Strub, T. Twine, F. Hall, and P. Sellers, eds. 2000. Collected Data of The Boreal Ecosystem-Atmosphere Study. NASA. CD-ROM.

Sellers, P. and F. Hall. 1994. Boreal Ecosystem-Atmosphere Study: Experiment Plan. Version 1994-3.0, NASA BOREAS Report (EXPLAN 94).

Sellers, P. and F. Hall. 1996. Boreal Ecosystem-Atmosphere Study: Experiment Plan. Version 1996-2.0, NASA BOREAS Report (EXPLAN 96).

Sellers, P., F. Hall, and K.F. Huemmrich. 1996. Boreal Ecosystem-Atmosphere Study: 1994 Operations. NASA BOREAS Report (OPS DOC 94).

Sellers, P., F. Hall, and K.F. Huemmrich. 1997. Boreal Ecosystem-Atmosphere Study: 1996 Operations. NASA BOREAS Report (OPS DOC 96).

Sellers, P., F. Hall, H. Margolis, B. Kelly, D. Baldocchi, G. den Hartog, J. Cihlar, M.G. Ryan, B. Goodison, P. Crill, K.J. Ranson, D. Lettenmaier, and D.E. Wickland. 1995. The boreal ecosystem-atmosphere study (BOREAS): an overview and early results from the 1994 field year. Bulletin of the American Meteorological Society. 76(9):1549-1577.

Sellers, P.J., F.G. Hall, R.D. Kelly, A. Black, D. Baldocchi, J. Berry, M. Ryan, K.J. Ranson, P.M. Crill, D.P. Lettenmaier, H. Margolis, J. Cihlar, J. Newcomer, D. Fitzjarrald, P.G. Jarvis, S.T. Gower, D. Halliwell, D. Williams, B. Goodison, D.E. Wickland, and F.E. Guertin. 1997. BOREAS in 1997: Experiment Overview, Scientific Results and Future Directions. Journal of Geophysical Research 102(D24): 28,731-28,770.

17.3 Archive/DBMS Usage Documentation

None.

\section{Glossary of Terms}

delta ${ }^{13} \mathrm{C}$, or $\mathrm{d}^{13} \mathrm{C}$ - stable carbon isotope ratio 


\section{List of Acronyms}

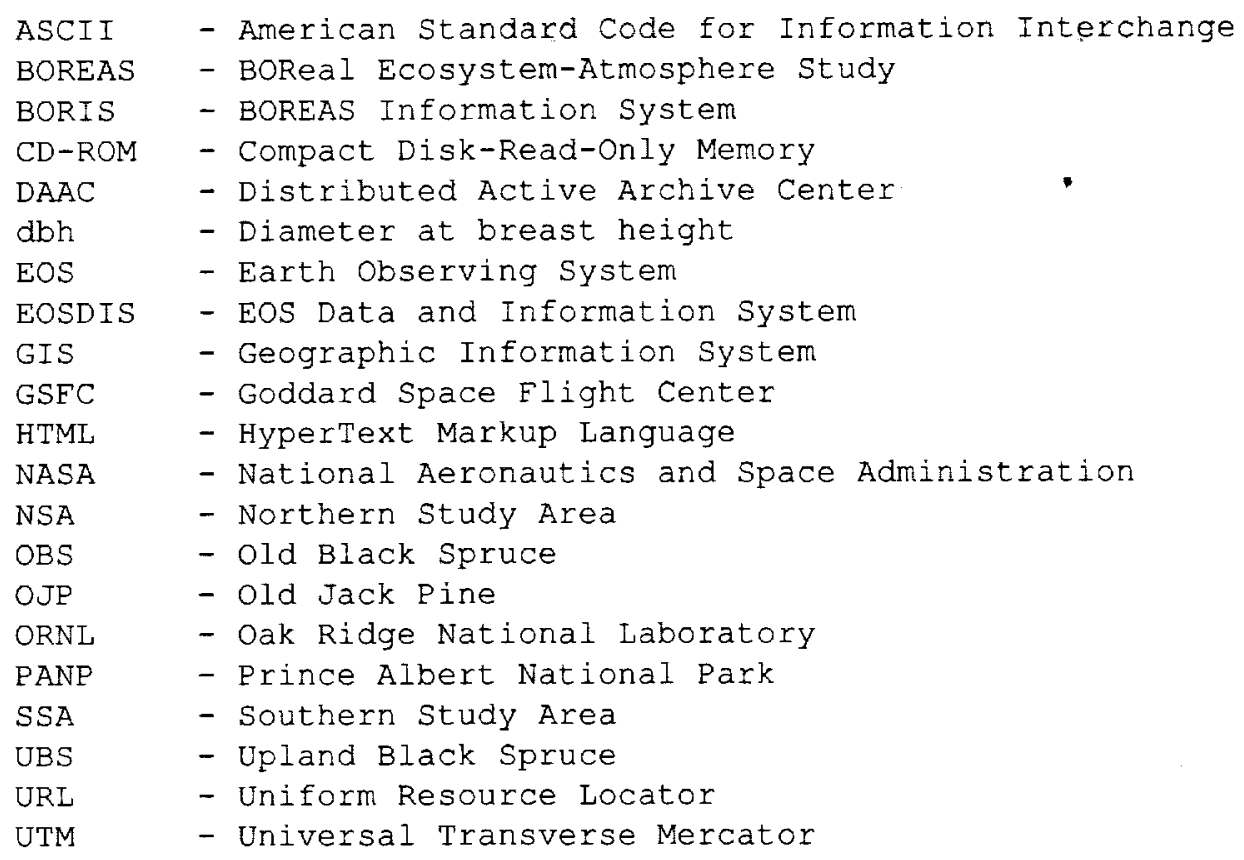

\section{Document Information}

20.1 Document Revision Date(s)

Written: 03-Apr-1997

Last Updated: 02-Jun-1999

\subsection{Document Review Date(s)}

BORIS Review: 18-Jun-1997

Science Review: 27-Jan-1998

\subsection{Document ID}

\subsection{Citation}

When using these data, please include the following acknowledgment as well as citations of relevant papers in Section 17.2:

The efforts of Jim Ehleringer, University of Utah; Larry Flanagan, Carleton University; and J. Renee Brooks, University of South Florida in collecting and providing these data are greatly appreciated.

If using data from the BOREAS CD-ROM series, also reference the data as:

Ehleringer, J. and L. Flanagan, "Vegetation-Atmosphere $\mathrm{CO}_{2}$ and $\mathrm{H}_{2} \mathrm{O}$ Exchange Processes: Stable Isotope Analyses." In Collected Data of The Boreal Ecosystem-Atmosphere Study. Eds. J. Newcomer, D. Landis, S. Conrad, S. Curd, K. Huemmrich, D. Knapp, A. Morrell, J. Nickeson, A. Papagno, D. Rinker, R. Strub, T. Twine, F. Hall, and P. Sellers. CD-ROM. NASA, 2000. 
Also, cite the BOREAS CD-ROM set as:

Newcomer, J., D. Landis, S. Conrad, S. Curd, K. Huemmrich, D. Knapp, A. Morrell, J. Nickeson, A. Papagno, D. Rinker, R. Strub, T. Twine, F. Hall, and P. Sellers, eds. Collected Data of The Boreal Ecosystem-Atmosphere Study. NASA. CD-ROM. NASA, 2000.

\subsection{Document Curator}

\subsection{Document URL}




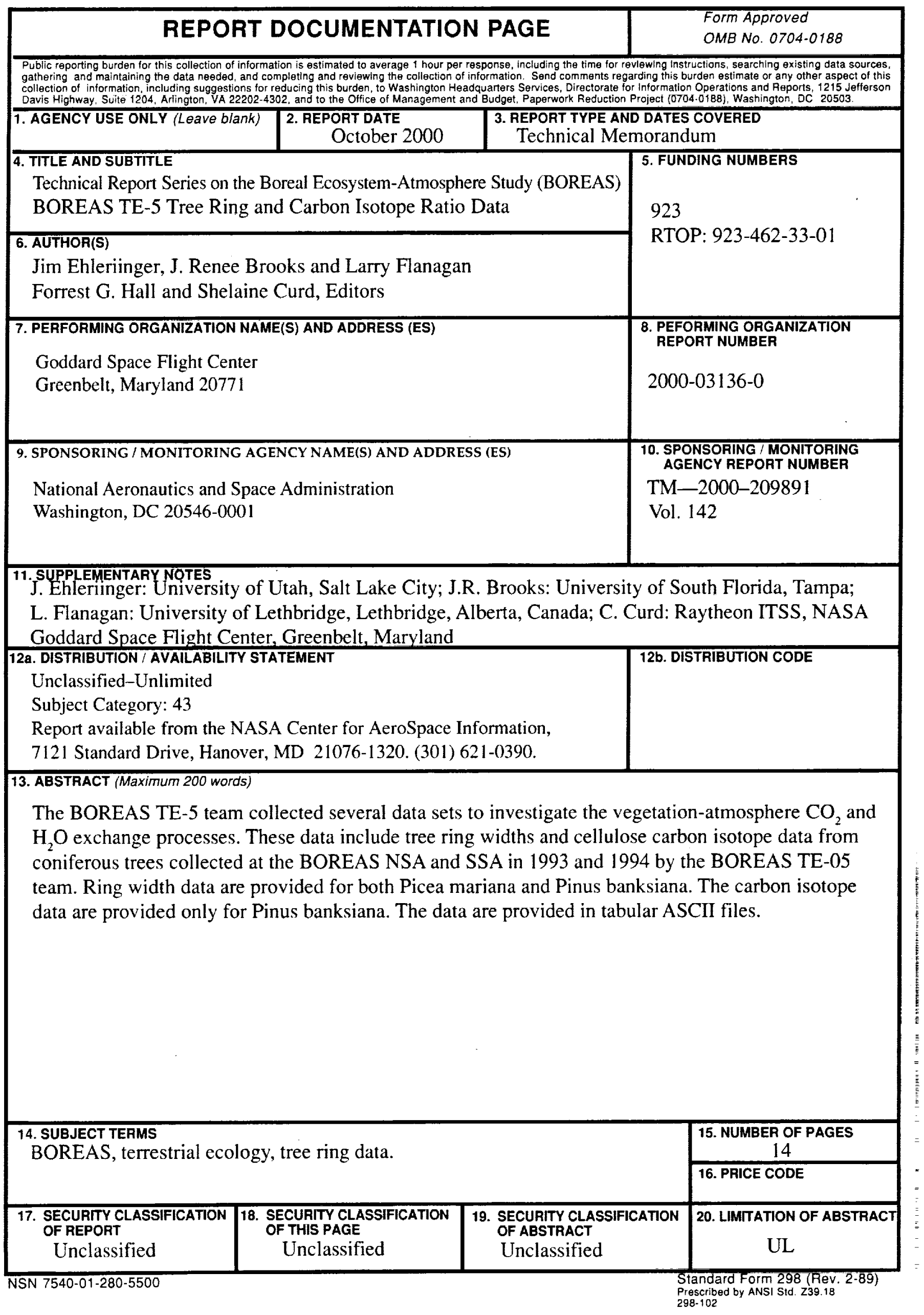

